\title{
Factors Influencing Professionals and Contractors' Resistance Behaviours towards Sustainable Construction Practices in Nigeria
}

\author{
Peter Uchenna Okoye ${ }^{1 *}$, Isaac Abiodun Odesola ${ }^{2}$, Obinna George Ogbuagu ${ }^{3}$, Chukwuemeka Ngwu ${ }^{4}$
}

\author{
${ }^{1}$ Department of Building, Nnamdi Azikiwe University, Awka, NIGERIA \\ ${ }^{2}$ Department of Building, University of Uyo, Uyo, NIGERIA \\ ${ }^{3}$ Department of Building, Federal University of Technology, Owerri, NIGERIA \\ ${ }^{4}$ Department of Quantity Surveying, Nnamdi Azikiwe University, Awka, NIGERIA \\ *Corresponding Author: pu.okoye@unizik.edu.ng
}

Citation: Okoye, P. U., Odesola, I. A., Ogbuagu, O. G. and Ngwu, C. (2021). Factors Influencing Professionals and Contractors' Resistance Behaviours towards Sustainable Construction Practices in Nigeria. European Journal of Sustainable Development Research, 5(2), em0155. https://doi.org/10.21601/ejosdr/10825

\section{ARTICLE INFO}

Received: 4 Aug. 2020

Accepted: 20 Jan. 2021

\begin{abstract}
This study examined the factors influencing construction professionals and contractors' resistance behaviours towards sustainable construction practices in Nigeria. 56 variables identified from literature were categorised into four main factors. Questionnaire was designed based on the extracted variables and distributed to construction professionals and contractors in South-East Nigeria. The data generated through the questionnaire survey were analysed using Statistical Package for Social Sciences (SPSS) Software. The result revealed that industry, policy, human, and environment factors were significantly influencing professionals and contractors' resistance behaviours to implementation of sustainable construction practices. However, the Mean Score Index result revealed that policy factors with an average MSI of 4.68 exert the greatest influence on professionals' and contractors' resistance behaviours. The overall result showed that all the variables have significant influences on professionals' and contractors' resistance behaviours, but five sub-factors (limited knowledge and awareness, additional cost of change, the prevailing economic condition, incompatibility of change process and organisational culture, and laws and regulations) each with an average MSI of 5.00 have the greatest individual influences on construction stakeholders' resistance behaviours towards sustainable construction practices in Nigeria. The Mann-Whitney U Test result affirmed that there is no significant difference $(p>0.05)$ between the rankings of professionals and contractors on the factors influencing their resistance behaviours. In view of this, the study raised concern about the training routes of the construction practitioners, conventional construction practices and existing policy and legislative frameworks including government commitment towards implementing sustainable construction practices in Nigeria.
\end{abstract}

Keywords: behaviours, contractors, professionals, resistance, sustainable construction practices

\section{INTRODUCTION}

The concept of resistance to change is ingrained in the Lewin's three-step organisational change model of unfreezing, moving and freezing of group standards (Lewin, 1947). This concept recognises the existence of driving forces that seek to either bring about or resist change in a given organisational setting. In spite of the fact that construction projects are agents or process of change (van Marrewijk, 2018), the changes in the construction practices have been much slower than expected to meet the tenets of sustainability (Bonanomi et al., 2016; Erdogan et al., 2005; Lines et al., 2015; Wong et al., 2018).

In the construction industry, the problems of resistance to change are identified as impediments to construction projects' improvement and implementation of sustainable construction practices (Ametepey et al., 2015; Pham et al., 2020; Powmya and Abidin, 2014). Successful implementation of new processes for procuring, contracting, and managing sustainable construction projects requires concerted change management efforts for owners of architectural, engineering, and construction industry (Erdogan et al., 2005; Lines et al., 2015). But for an inexperienced or incompetent construction practitioner it is difficult due to new technology, additional design requirement and rigorous practices (Powmya et al., 2019).

Forsell and Åström (2012) reason that resistance to change can be the cause of this difficulty when it is either too strong or too weak. It can also have affective, cognitive and behavioural components that create a psychological resistance to making a change in particular situations. According to 
Harich (2010), "resistance to change is the tendency for a system to continue its current behaviour, despite the application of force to change that behaviour". Resistance itself is a representation of different power relations in an organisation that has aptitude to sway the cause of the change process (Courpasson and Vallles, 2016); any dissenting actions that slow, oppose and/or obstruct a change effort (Armenakis and Harris, 2009); or as observable deeds, conduct, and event that prevent the cause of change (Fiedler, 2010; Lines et al., 2014). Meanwhile, three dimensions of resistance to change (cognitive, effective and behavioural) have been recognised in the literature (Chung et al., 2012; Forsell and Åström, 2012; Pakdel, 2016; Smollan, 2011; Thakur and Srivastava, 2018). Resistance to change could be a combination of cognitive, effective or emotional, and behavioural or intentional components (Bouckenooghe, 2010). Behavioural dimension arises when the forces of resistance are applied against the forces of change (Hadavinejad et al., 2010) or action responses against the change, (Lines et al., 2015). Affective dimension deals with individual's failure due to decline of existing situation, emotional attachment about the change, fear of probable loss and imprecise future (Hadavinejad et al., 2010). Whereas cognitive dimension depicts how change is perceived by the individuals that they are reluctant to initiate it (Hadavinejad et al., 2010).

Nevertheless, resistance to change cannot ordinarily occur. Amarantou et al. (2018) and Karaxha (2019) attributed many reasons of failure of change initiatives to resistance to change. Other studies also identified culture of resistance to change behaviour as key issue militating against the implementation of sustainable construction practices in the construction industry (Al Amri and Marey-Pérez, 2020; Ametepey et al., 2015; Djokoto et al., 2014; Olowosile et al., 2019; Pham et al., 2020; Powmya and Abidin, 2014; Wong et al., 2018). Specifically, Harich (2010) and Harich et al. (2012) link the failure of human system to solve the problems of sustainability over the last two decades to the resistance to change. Wong et al. (2018) identifies resistance to practice change within the contractors' firms as one of the key barriers to more extensive adoption of prefabrication. Harich et al. (2012) further queries the opposition of changes from an unsustainable to a sustainable behaviour by the human system. According to Hammond et al. (2019), the reluctance to adopt sustainable construction practices by the construction stakeholders is usually demonstrated at the individual level of choice.

Regrettably, whether resistance to change behaviour towards sustainable construction practices among construction professional and contractors is customary is yet to be fully explored. Furthermore, whether the factors influencing their resistance to change behaviours towards the implementation of sustainable construction practices differ, is a subject of determination. Pieterse et al. (2012) suggest that resistance to change studies should consider different professional cultures in cross-functional project teams. Consequently, understanding the factors influencing professionals' and contractors' resistance behaviours towards sustainable construction practices vis-à-vis the differences in their perceptions, would explain why they oppose or promote such changes that can lead to sustainable construction.

\section{LITERATURE REVIEW}

Some studies have focused on the behavioural resistance to change (Bovey and Hede, 2001; Fiedler, 2010; Langstrand and Elg, 2012; Lines et al., 2015, Macrì et al., 2002; van Marrewijk, 2018). Whereas very few studies have actually looked at the factors influencing resistance to change in the workplace (Amarantou et al., 2016; 2018; Damawan and Azizah, 2020; Khan, Raza and Mujtaba, 2016; Ybema, Thomas and Hardy, 2016). Table 1 is a summary of literature on the variables responsible for resistance to change behaviour.

From the foregoing literature, impliedly, it is obvious that there are many impediments to the implementation of sustainable construction practices. However, literature is silent on the factors influencing resistance behaviours of construction professionals and contractors towards the implementation of sustainable construction practices in Nigeria, and the extent these factors influence the professionals and contractors' behaviours. These are the thrust of this study and the gap in the literature to which this study was set to fill. The aim of this study therefore, is to examine the factors influencing construction professionals and contractors' resistance behaviours towards the implementation of sustainable construction practices in Nigeria. It would also investigate if there is any significant difference between the rankings of the professionals' and contractors' on their perceptions of the factors responsible for resistance to change behaviours.

\section{Hypothesis}

$\mathbf{H}_{\mathbf{0}}$ : There is no significant difference between the perceptions of professionals' and contractors' on the ratings of factors responsible for change behaviours.

\section{METHODOLOGY}

This study is a survey research that made use of structured questionnaires distributed to the building construction consultants/professionals and contractors in the South-East of Nigeria. 315 respondents each from the professionals and contractors' groups were randomly selected from the population of 728 professionals and 989 contractors. This was obtained from the tenders' board of the five states of South East Nigeria in the last five years without repetition, and the register of various professional associations. The sample for the study was based on the calculated sample size using Cochran's sample size calculation (Cochran, 1977). 95\% confidence interval and a margin of error of $5 \%$ were assumed to be acceptable for this kind of study (Bartlett et al., 2001; Gilliland and Melfi, 2010; Taherdoost, 2017).

Prior to the distribution of the questionnaires, the locations and contacts of most of the prospective respondents were first identified and their consent/permission was sought. The objectives of the study were clearly explained and those who refused to grant permission were skipped from the survey. The initial familiarisation made the actual survey easier because the respondents were already aware of what was expected of them. 
Table 1. A summary of variables responsible for resistance to change behaviour

\begin{tabular}{cc}
\hline Sources & Resistance to Change Variables \\
\hline Aghimien et al., 2019b; Fauzi et al., 2018; Sarhan et al., 2018 & End-user/client perception and preference \\
\hline Amarantou et al., 2016; Khan and ur Rehman, 2008 & Perception that it is bad business \\
\hline Khourshed, 2011 & Lingering resentment \\
\hline Lack of confidence \\
\hline Damawan and Azizah, 2020; Davies and Davies, 2017; Khourshed, 2011 & Loss of face and reputation \\
\hline Ametepey et al., 2015; Angonese and Lavarda, 2014; Djokoto et al., 2014; Fauzi et al., & Insufficient stakeholder drive \\
\hline 2018 & The fear of potential embarrassment \\
\hline Damawan and Azizah, 2020; Khan and ur Rehman, 2008; Macrì et al., 2002 & Threats to existing balance of power, \\
\hline Macrì et al., 2002; Ybema et al., 2016 & Intergroup conflicts that inhibit cooperation \\
\hline Amarantou et al., 2018; Djokoto et al., 2014; Macrì et al., 2002; Susanti et al., 2019 & Degree of tolerance and formalisation \\
\hline Angonese and Lavarda, 2014 & Job security \\
\hline Amarantou et al., 2018; Angonese and Lavarda, 2014; Damawan and Azizah, 2020 & Previous experience \\
\hline Khan and ur Rehman, 2008; Khourshed, 2011 & Scepticism about the need for change
\end{tabular}

Aghimien et al., 2019a; Aghimien et al., 2019b; Ametepey et al., 2015; Angonese and

Lavarda, 2014; Davies and Davies, 2017; Djokoto et al., 2014; Lee et al., 2014; Schweiger et al., 2018

Angonese and Lavarda, 2014; Khan and ur Rehman, 2008

Damawan and Azizah, 2020; Khan and ur Rehman, 2008 Esezobor, 2016

Damawan and Azizah, 2020

Ametepey et al., 2015; Bonanomi et al., 2016; Djokoto et al., 2014 Ametepey et al., 2015

Ametepey et al., 2015; Esezobor, 2016

Aghimien et al., 2019b; Gunduz and Almuajebh, 2020; Davies and Davies, 2017; Khan et al., 2016

Limited knowledge and awareness

Trust/distrust about the change Level of stress and anxiety involve Work values

Curiosity of difference

Unstable investment requirements Construction cycles

Fragmented construction market procurement

Additional cost of change

Macrì et al., 2002; Ybema et al., 2016

Aghimien et al., 2019a; Ametepey et al., 2015; Esezobor, 2016; Hoxha and Shala, 2019; Pham et al., 2019 Khan et al., 2016

Bonanomi et al., 2016; Langstrand and Elg, 2012

Changing work profile and inflexibility

Lack of industry familiarity with new construction techniques Demanding and tight project schedule Inefficient processes and fragmented supply chains

Ametepey et al., 2015; Davies and Davies, 2017; Esezobor, 2016; Langstrand and Elg, 2012; Lee et al., 2014

Complexity and expensive systems of construction project

Gunduz and Almuajebh, 2020 Esezobor, 2016;

Khan et al., 2016; van Marrewijk, 2018

Gunduz and Almuajebh, 2020
Esezobor, 2016;

Ametepey et al., 2015; Angonese and Lavarda, 2014; Singh, 2015 Djokoto et al., 2014

Ametepey et al., 2015; Daniel et al., 2018; Djokoto et al., 2014; Gunduz and Almuajebh, 2020; Pham et al., 2019

Ametepey et al., 2015; Macrì et al., 2002; Susanti et al., 2019

Onubi et al., 2019

Lines et al., 2015

Ametepey et al., 2015; Pham et al., 2019

Aghimien et al., 2019a; Djokoto et al., 2014; Susanti et al., 2019 Singh, 2015

Amarantou et al., 2018; Djokoto et al., 2014; Macrì et al., 2002; Pham et al., 2019

Macrì et al., 2002

Ybema et al., 2016

Damawan and Azizah, 2020; Khan et al., 2016; Langstrand and Elg, 2012

Macrì et al., 2002; Ybema et al., 2016

Ametepey et al., 2015; Daniel et al., 2018; Davies and Davies, 2017; Djokoto et al., 2014

Damawan and Azizah, 2020; Hoxha and Shala, 2019 Onubi et al., 2019

Ametepey et al., 2015; Davies and Davies, 2017; Djokoto et al., 2014; Macrì et al., 2002

Ametepey et al., 2015; Bonanomi et al., 2016; Djokoto et al., 2014; Fauzi et al., 2018;

Gunduz and Almuajebh, 2020; Pham et al., 2019

Ametepey et al., 2015; Davies and Davies, 2017; Djokoto et al., 2014 Ametepey et al., 2015; Djokoto et al., 2014

Lines et al., 2015

Davies and Davies, 2017; Khan et al., 2016

Amarantou et al., 2018; Angonese and Lavarda, 2014; Gunduz and Almuajebh, 2020; Langstrand and Elg, 2012

Aghimien et al., 2019a; Ametepey et al., 2015; Davies and Davies, 2017; Djokoto et al.,

2014; Gunduz and Almuajebh, 2020; Hoxha and Shala, 2019
Legacy of sunk costs

Site-based nature of construction project Lack of time to implement or learn a new a new technology or process

A reward system that reinforces old ways of doing things Additional design and construction requirements

Lack of skilled management and supervising team

Skills and labour supply problems

Health and safety implications

Transport infrastructure and equipment availability Limited resources

Selective information processing Increased workload

Lack of project team support

Prevailing economic condition Existing competitors

Existing trends or traditions

Work environment and society Demand fluctuations

Incompatibility of change process and organisational culture Impact on environment

Standardisation and scalability

Government commitment

Heavy investment in previous decisions and courses of action Professional ethics and practices

Problem of reallocation of resources

Weakness of the proposed changes

Bureaucratic inertia

Laws and regulations

Operational strategy 
The questionnaire was randomly distributed to each of the group of the respondents up to the required sample size. The distribution was done through mail and by hand. 127 professionals and 161 contractors completely filled and returned their questionnaires which were used in the analysis. This represented about $40.32 \%$ and $51.11 \%$ response rate respectively. The same set of questionnaire comprising of two parts was distributed to the two groups of respondents. Part 1 captured respondents' demographic information. Part 2 contained four main factors with 56 latent variables extracted from the literature as shown in Table 1. The variables measure the factors responsible for resistance to change towards the implementation of sustainable construction practices in Nigeria. The respondents were asked to rate the factors influencing their behaviours towards resisting of the implementation of sustainable construction practices on a 5point Likert Scale. Where $1=$ Very insignificant, $2=$ Insignificant, 3 = Neutral, 4 = Significant, 5 = Very Significant.

The respondents to this study were building construction contractors and professionals. The professionals are the architects, builders, quantity surveyors, and engineers who provide professional services in the form of consultancy and other professional services in line with their trainings and statutory provisions in the construction practice. Contractors are representatives of construction organisations or firms involved in the execution of construction projects in line with the contractual agreements. Although there are many players in the building construction industry, the actual implementation of any change in the construction processes lies on the contractors and professionals (Adros and Abidin, 2019; Alzahrani and Emsley, 2012; Hussin and Omran, 2009). Hence the importance of these stakeholders in the implementation of sustainable construction practices.

The data generated from the survey were subjected to descriptive and quantitative analyses. The internal consistency of the research instrument was determined using the Cronbach's Alpha $(\alpha)$. The Cronbach's Alpha > 0.6 would imply that the instrument for data collection for this survey is reliable and acceptable (Ekolu and Quainoo, 2019; Tavakol and Dennick, 2011). Subsequently, the Mean Score Index (MSI) was computed to determine the level of effects of resistance factors on the attitudes of professionals and contractors towards the implementation of sustainable construction practices. MannWhitney $\mathrm{U}$ test statistic was conducted to determine significant difference in the ranking of the resistance to change factors between the professionals and contractors. The whole statistical analysis was done using SPSS Version 22 . The MSI is computed using Equation 1.

$$
M S I=\frac{\sum f_{i} x_{i}}{N}
$$

Where MSI = mean score index; $f=$ frequency of responses to each rating scale (integer value (i) between 1 and 5 ), $x=$ score or rating given to each variable by the respondents; and $N=$ total number of the respondents selecting a rating equal to $i$.
Table 2. Respondents background information

\begin{tabular}{|c|c|}
\hline Variable & Responses (\%) \\
\hline \multicolumn{2}{|l|}{ Category of Respondents } \\
\hline Professional & 44.10 \\
\hline Contractor & 55.90 \\
\hline \multicolumn{2}{|l|}{ Organisational affiliation } \\
\hline Consultancy & 22.57 \\
\hline Contracting & 36.81 \\
\hline Academics & 25.69 \\
\hline Consultancy/Contracting & 14.93 \\
\hline \multicolumn{2}{|l|}{ Professional affiliation } \\
\hline Building & 8.68 \\
\hline Architecture & 21.18 \\
\hline Engineering & 31.25 \\
\hline Quantity Surveying & 16.67 \\
\hline Estate Management & 4.51 \\
\hline Others & 17.71 \\
\hline \multicolumn{2}{|l|}{ Registered member of professional body } \\
\hline Yes & 72.22 \\
\hline No & 27.78 \\
\hline \multicolumn{2}{|l|}{ Job Position } \\
\hline Project/Construction Manager & 15.28 \\
\hline Project Engineer & 23.26 \\
\hline Consultant & 14.58 \\
\hline Supervisor & 24.31 \\
\hline Director & 6.25 \\
\hline Others & 16.32 \\
\hline \multicolumn{2}{|l|}{ Educational Level } \\
\hline Primary & 2.78 \\
\hline Secondary & 9.03 \\
\hline Higher institution & 50.69 \\
\hline Post-graduate & 29.86 \\
\hline Others & 7.64 \\
\hline \multicolumn{2}{|l|}{ Years of Working Experience } \\
\hline $0-5$ years & 13.19 \\
\hline 6-10 years & 14.93 \\
\hline $11-15$ years & 20.49 \\
\hline $16-20$ years & 42.71 \\
\hline Above 20 years & 8.68 \\
\hline
\end{tabular}

\section{RESULT AND DISCUSSION}

\section{Background Information}

Table 2 displayed the background information of the respondents. Based on the information primarily provided on education level, professional affiliations, years of experience and job positions, it shows that the respondents are suitable for the study.

\section{Analysis of Factors Responsible for Resistance Behaviours towards Sustainable Construction Practices}

Table 3 presented the result of the analyses of the MSI and consistency test of factors responsible for resistance behaviours towards sustainable construction practices in Nigeria. The result showed that the Cronbach's Alpha $(\alpha)$ values for all the factors responsible for professionals and contractors' resistance to change behaviours towards sustainable construction practices were $>0.6$. This implies that the research instrument was reliable, and therefore, can be used as instrument for data collection. It also implies that the test of construct reliability and internal consistency have been satisfied. 
Table 3. MSI of factors responsible for resistance to change behaviours of construction professionals' and contractors' towards sustainable construction practices

\section{S/N Resistance to Change Factors}

Human (Cronbach's Alpha $=.726)$

$1 \quad$ End-user/client perception

MS

Average

2 Perception that it is bad business

Professionals

3 Lingering resentment

$4 \quad$ Lack of confidence

$5 \quad$ Loss of face and reputation

$6 \quad$ Insufficient stakeholder drive

$7 \quad$ The fear of potential embarrassment

8 Threats to existing balance of power,

$9 \quad$ Intergroup conflicts that inhibit cooperation

$10 \quad$ Degree of tolerance and formalisation

$11 \quad$ Job security

$12 \quad$ Previous experience

13 Scepticism about the need for change

$14 \quad$ Limited knowledge and awareness

15 Trust/distrust about the change

16 Level of stress and anxiety involve

$17 \quad$ Work values

$18 \quad$ Curiosity of difference

\section{Average Mean}

Industry (Cronbach's Alpha $=\mathbf{~ . 7 0 5 )}$

\begin{tabular}{lll}
\hline 1 & Unstable investment requirements & 4.74
\end{tabular}

\begin{tabular}{lll}
\hline 2 & Construction cycles & 3.54
\end{tabular}

\begin{tabular}{lll}
\hline 3 & Fragmented construction market procurement & 4.57
\end{tabular}

\begin{tabular}{lll}
\hline $4 \quad$ Additional cost of change & 5.00
\end{tabular}

$5 \quad$ Changing work profile and inflexibility 3.82

\begin{tabular}{lll}
\hline 6 & Lack of industry familiarity with new construction techniques & 4.71
\end{tabular}

$7 \quad$ Demanding and tight project schedule

$8 \quad$ Inefficient processes and fragmented supply chains 4.46

\begin{tabular}{lll}
\hline 9 & Complexity and expensive systems of construction project & 4.85
\end{tabular}

\begin{tabular}{lll}
\hline $10 \quad$ Legacy of sunk costs & 3.74
\end{tabular}

\begin{tabular}{lll}
\hline 11 & Site-based nature of construction project & 3.79
\end{tabular}

$\begin{array}{lll}12 & \text { Lack of time to implement or learn a new a new technology or process } & 4.27\end{array}$

\begin{tabular}{lll}
\hline 13 & A reward system that reinforces old ways of doing things & 4.03
\end{tabular}

\begin{tabular}{lll}
\hline 14 & Additional design and construction requirements & 4.80 \\
\hline
\end{tabular}

$15 \quad$ Lack of skilled management and supervising team

$16 \quad$ Skills and labour supply problems

Average Mean

$\begin{array}{lll}4.89 & 4.89 & 4.89\end{array}$

$\begin{array}{lll}4.14 & 4.53 & 4.34\end{array}$

$\begin{array}{lll}4.33 & 4.39 & 4.36\end{array}$

$\begin{array}{lll}4.52 & 4.75 & 4.64\end{array}$

$3.61 \quad 4.40$

$4.26 \quad 4.69$

$4.32 \quad 4.71$

$4.35 \quad 4.27$

4.78

$4.67-4.68$

$4.25 \quad 4.23$

4.83

5.00

4.85

4.94

4.95

4.67

.76

4.89

4.65

4.69

4.91

4.68

4.01

4.48

Environment (Cronbach's Alpha = .786)

\begin{tabular}{lll}
\hline 1 & Health and safety implications & 4.87
\end{tabular}

2 Transport infrastructure and equipment availability

$3 \quad$ Limited resources

$4 \quad$ Selective information processing

$5 \quad$ Increased workload

$6 \quad$ Lack of project team support

$7 \quad$ The prevailing economic condition

$8 \quad$ Existing competitors

$9 \quad$ Existing trends or traditions

$10 \quad$ Work environment and society

11 Demand fluctuations

12 Incompatibility of change process and organisational culture

13 Impact on environment

\section{Average Mean}

Policy (Cronbach's Alpha = .745)

1 Standardisation and scalability

$2 \quad$ Government commitment

3 Heavy investment in previous decisions and courses of action

$4 \quad$ Professional ethics and practices

$5 \quad$ Problem of reallocation of resources

$6 \quad$ The weakness of the proposed changes

$7 \quad$ Bureaucratic inertia

$8 \quad$ Laws and regulations

$9 \quad$ Operational strategy

\section{Average Mean}

\begin{tabular}{l}
4.74 \\
\hline .54 \\
4.57 \\
5.00 \\
3.82 \\
\hline .71 \\
4.58 \\
4.46 \\
\hline .85 \\
\hline .74 \\
\hline .79 \\
4.27 \\
4.03 \\
4.80 \\
4.84 \\
\hline .80
\end{tabular}

4.80

4.41

5.00

3.75

4.73

5.00

4.53

4.81

4.77

4.93

5.00

4.32

3.93

4.62

4.04

4.86

4.88

4.96

4.63

4.52

4.31

4.62

.68

4.84

4.90

5.00

4.92

4.48

4.68

4.84

4.57

\begin{tabular}{lll}
\hline 4.87 & 5.00 & 4.94 \\
\hline 3.49 & 3.40 & 3.45 \\
\hline .58 & 4.92 & 4.75 \\
\hline 3.33 & 4.27 & 3.80 \\
\hline 3.45 & 4.52 & 3.99 \\
\hline 4.09 & 4.64 & 4.37 \\
\hline 5.00 & 5.00 & 5.00 \\
\hline 3.95 & 4.76 & 4.36 \\
\hline 4.17 & 4.85 & 4.51 \\
\hline 4.79 & 4.90 & 4.85 \\
\hline 4.66 & 4.58 & 4.62 \\
\hline 5.00 & 5.00 & 5.00 \\
\hline 4.88 & 4.88 & 4.88 \\
\hline 4.31 & 4.62 & 4.47 \\
\hline & & \\
\hline 4.72 & 4.69 & 4.71 \\
\hline 4.96 & 4.97 & 4.97 \\
\hline 4.75 & 4.93 & 4.84 \\
\hline 4.69 & 4.71 & 4.70 \\
\hline 3.91 & 4.65 & 4.28 \\
\hline 4.63 & 4.94 & 4.79 \\
\hline 3.68 & 4.46 & 4.07 \\
\hline 5.00 & 5.00 & 5.00 \\
\hline 4.57 & 4.94 & 4.76 \\
\hline 4.54 & 4.81 & 4.68 \\
\hline & & \\
\hline
\end{tabular}


Table 4. Result of Mann-Whitney U Test

\begin{tabular}{ccccc}
\hline & \multicolumn{2}{c}{ Test Statistics $^{\mathbf{a}}$} & & \\
\hline & Human & Industry & Environment & Policy \\
\hline Mann-Whitney U & $9.980 \mathrm{E} 3$ & $9.848 \mathrm{E} 3$ & $9.382 \mathrm{E} 3$ & $9.772 \mathrm{E} 3$ \\
\hline Wilcoxon W & $2.302 \mathrm{E} 4$ & $2.289 \mathrm{E} 4$ & $2.242 \mathrm{E} 4$ & $2.281 \mathrm{E} 4$ \\
\hline Z & -.347 & -.536 & -1.204 & -.650 \\
\hline Asymp. Sig. (2-tailed) & .728 & .592 & .229 & .516 \\
\hline
\end{tabular}

a. Grouping Variable: Category of Respondents

Statistical significance at $5 \%$

Table 5. Result of Mean Rank from Mann-Whitney U Test

\begin{tabular}{|c|c|c|c|c|}
\hline \multicolumn{5}{|c|}{ Ranks } \\
\hline Factors & Category of Respondents & $\mathbf{N}$ & Mean Rank & Sum of Ranks \\
\hline \multirow{3}{*}{ Human } & Professionals & 127 & 146.41 & 18594.50 \\
\hline & Contractors & 161 & 142.99 & 23021.50 \\
\hline & Total & 288 & & \\
\hline \multirow{3}{*}{ Industry } & Professionals & 127 & 147.46 & 18727.00 \\
\hline & Contractors & 161 & 142.17 & 22889.00 \\
\hline & Total & 288 & & \\
\hline \multirow{3}{*}{ Environment } & Professionals & 127 & 151.13 & 19193.50 \\
\hline & Contractors & 161 & 139.27 & 22422.50 \\
\hline & Total & 288 & & \\
\hline \multirow{3}{*}{ Policy } & Professionals & 127 & 148.05 & 18802.50 \\
\hline & Contractors & 161 & 141.70 & 22813.50 \\
\hline & Total & 288 & & \\
\hline
\end{tabular}

The factors responsible for influencing construction professionals' and contractors' resistance behaviours to the implementation of sustainable construction practices in Nigeria were classified into four groups as: Human, Industry, Environment and Policy. The average MSI of these factors (Human $=4.57$, Industry $=4.52$, Environment $=4.47$ and Policy $=4.68$ ) suggested that they are significantly influencing the professionals and contractors' resistance behaviours, since the average MSI of each of the groups of factors is $>4.00$. However, the higher the MSI, the greater the level of influence on the professionals and contractors' resistance behaviours. Amidst the four main factors, the result showed that policy especially through laws and regulations, and government commitments have the greatest influence on the behaviours of the professionals and contractors to resist change towards sustainable construction practices in Nigeria. This may be indication that weak policy or legal framework encourages practitioners to resist change towards sustainable construction practices.

Furthermore, the MSI of the 56 variables in Table 3 suggested that all the variables have potentials to influence the behaviours of the construction professionals and contractors to resist changes towards sustainable construction practices in Nigeria. The average MSI of the factors range from 3.45 for transport infrastructure and equipment availability to 5.00 for limited knowledge and awareness, additional cost of change, the prevailing economic condition, incompatibility of change process and organisational culture and laws and regulations. The five variables with MSI of 5.00 each signified that they have the greatest influence on the professionals and contractors' behaviours to resist change. That is to say that, though other variables have great potentials to influence the professionals and contractors' behaviours to resist change; limited knowledge and awareness, additional cost of change, the prevailing economic condition, incompatibility of change process and organisational culture and laws and regulations are very critical to the professionals and contractors' behaviours to resist change towards sustainable construction practices in Nigeria. This further underscores the importance of these variables in the implementation of sustainable construction in the building construction industry. It also shows the need for special considerations on the variables in an effort towards implementation of sustainable construction practices in Nigeria.

The significance of the difference in the rankings of the resistance factors between the professionals and contractors was tested for each of the four main factors using the MannWhitney U Test, the results are presented in Tables 4 and 5 .

The result in Table 4 revealed that there is no significant difference between the rankings of the professionals and contractors of the factors influencing their resistance behaviours towards sustainable construction practices. Specifically, the Mann-Whitney U test result for human factor indicated that $\mathrm{U}=9.980 \mathrm{E} 3, \mathrm{Z}=-.347$, and $p=.728>.05$ ). The Mann-Whitney $U$ test result for industry factor indicated that $\mathrm{U}=9.848 \mathrm{E} 3, \mathrm{Z}=-.536$, and $p=.592>.05)$. The result for environment factor showed that $\mathrm{U}=9.382 \mathrm{E} 3, \mathrm{Z}=-1.204$, and $p$ $=.229>.05$ ). Similarly, the Mann-Whitney U test result for policy factor indicated that $\mathrm{U}=9.772 \mathrm{E} 3, \mathrm{Z}=-.650$, and $p=.516$ $>$.05. Consequently, the null hypothesis is accepted in all cases. It signifies that the factors influencing resistive behaviours of professionals and contractors towards the implementation of sustainable construction practices are not different between the two groups of respondents. Hence, it affirmed that resistance to change factors influence the behaviours of professionals and contractors towards implementing sustainable construction practices in about the same way and magnitude. 
The result of this study has highlighted the importance of certain factors that trigger the decisions of construction professionals and contractors to resist changes and at the same time their resistance to change behaviours towards sustainable construction practices. The result revealed that while all the four main factors have significant influences on the resistance to change decisions and behaviours of construction stakeholders, policy factors exert the greatest influence followed by human factors, industry factors, and environmental factors respectively. This suggests that construction practices in Nigeria are still entangled with fundamental issues bothering on policy frameworks, individual characteristics and organisational culture. For example, lack of individual knowledge, belief and perception; the structure and nature of construction practices and procurement routes; the technicalities and skill requirements, weak and polarised policy frameworks, and lack of government commitments are fundamental issues militating against the implementation of sustainable construction practices in Nigeria (Aghimien et al., 2019a; Aghimien et al., 2019b; Daniel et al., 2018; Davies and Davies, 2017; Djokoto et al., 2014). Contrarily, adequate knowledge, integrated procurement systems, and strong policy framework through regulations, laws and government commitment would inhibit such resistance to change towards sustainable construction practices.

Generally, the overall mean score result of all the 56 variables in Table 3 showed that every variable has at least certain level of influence on the resistance to change decisions and behaviours of the professionals and contractors towards sustainable construction practices. This implies that these variables are very important and need to be considered while devising any means of promoting sustainable construction practices in Nigeria. However, the five individual variables with average MSI 5.00 each have the greatest influences and are very critical to the behaviours of professionals and contractors to resist changes towards sustainable construction practices in Nigeria. These variables have pivotal influence on the resistance to change behaviours or decisions of the construction stakeholders. The variables include: limited knowledge and awareness, additional cost of change, the prevailing economic condition, incompatibility of change process and organisational culture, and laws and regulations. This further implies that there is tendency of construction professionals and contractors to resist changes towards sustainable construction practices when they do not have adequate knowledge and limited awareness about the change. It also meant that the chances of the professionals and contractors to resist changes towards implementation of sustainable construction practices would increase when they perceive that the change would add significant costs to the project. Moreover, it is an indication that when the client or initiator of the project is not in good economic standing or when the project does not guarantee good profitability, the tendency of the professionals and contractors to resist any change perceived to suit the economy of the client is likely to be high. Relatively, it implies that when the change is not compatible with the organisational goals in addition to weak legislative framework, the practitioners are likely to resist such change.
The Mann-Whitney $U$ test results indicated that the influence of the four main groups of factors on the behaviours of the professionals and contractors towards the implementation of sustainable construction practices are experienced in about the same way irrespective of designations and roles. Therefore, a holistic measure which encompasses the characteristics of the professionals and contractors is more desirable to overcoming the resistive factors influencing the sustainable construction practices implementation in Nigeria.

The strength of this study lies in its findings. While other studies have focused on different organisations other than construction, this study was carried out within the framework of construction organisation setting. However, this result may not be generally applied across Nigeria. The sample size is too small to be generalised when compared to the number of building contractors and professionals in Nigeria. However, this could be a pointer to what is obtainable in the construction industry and practice across Nigeria since the construction players operate in the same construction systems, economic and political environment. Furthermore, the study failed to consider the opinion of the clients' group as a critical stakeholder in the implementation of any change in construction project.

This result, however, supports that of Sarhan et al. (2018) who revealed that there was no significant difference in barriers to implementation of lean construction among construction professionals based on organisational and individual characteristics. This study is also in line with the result of Amarantou et al. (2018), though in health sector which suggested that resistance to change is indirectly and directly influenced by many factors. It complemented Langstrand and Elg (2012) who recognised that the physical environmental resistance could result from the decisions and intentions to resist changes which are human factors. The result of this study is also supported by that of Ametepey et al. (2015), Angonese and Lavarda (2014), and Bonanomi et al. (2016) which identified certain critical factors that are responsible for resistance to change in an organisation. Furthermore, the result aligned with that of Schweiger et al. (2018) who proposed that with participatory strategy and increase awareness about change, there would be less resistance to change.

\section{CONCLUSION AND RECOMMENDATIONS}

The need to implement sustainable construction practices at all levels of construction practice has been highlighted. Many efforts have also been made towards the actualisation of sustainable construction practices. However, sustainable construction practices are facing intense hurdles due to resistance to change behaviours of construction players. Within the construction organisations, construction practitioners are resisting certain actions that would have brought about sustainable construction practices. These decisions, intentions or behaviours to resist changes towards sustainable construction practices by construction practitioners are informed by certain factors. This study therefore, has identified and examined the factors responsible 
for construction practitioners' resistance to change decisions and behaviours towards the implementation of sustainable construction practices in Nigeria.

The study has identified 56 variables which were grouped into four main factors: Human, Industry, Environment and Policy. The study demonstrated that construction professionals and contractors' behaviours to resist change towards sustainable construction practices are significantly influenced by these four main factors both at micro and macro levels. It further established that five variables that cut across the four main factors which include: Limited knowledge and awareness, additional cost of change, the prevailing economic condition, incompatibility of change process and organisational culture, and laws and regulations are critical to the behaviours of construction practitioners towards resistance to change. This implies that these variables possessed the greatest individual resistance to sustainable construction practices. Therefore, ignoring the variables could be fatal to the implementation of sustainable construction practices in Nigeria. Specifically, the study has highlighted the significance of policy, human and industry factors among other factors through the instrumentality of adequate training and knowledge about sustainable construction practices, government commitment and enabling laws and regulations, and adoption of integrated procurement systems that would restructure and change the conventional construction practices in Nigeria.

Without doubt, this study recognises the importance of social, physical and economic issues in taking decisions about resistance to change towards sustainable construction practices in Nigeria. It raises concern for a shift from conventional system of construction practices. It also queries the existing policy and legislative frameworks and the level of government commitment towards the implementation of sustainable construction practices in Nigeria. It raises further concern about the training routes of construction professionals and contractors. This study, therefore, has both practical and policy implications. Practically, it shows that there is still limited knowledge and awareness about the tenets of sustainable construction among construction stakeholders, which could be tamed through education and training. It also shows the need for a paradigm shift from what it is (traditional) to what it is supposed to be (integrated). Policy wise, it shows the deficiency and /or inadequacy of economic regenerative mechanisms, construction policies, government commitment, legislative frameworks and enabling laws for construction practices in Nigeria. Above all, it has added to the growing body of knowledge especially in the areas of organisational change and sustainable construction.

Finally, this study recommended for reinvigoration of legislative framework for sustainable construction practices with increased government commitments; training and retraining of construction practitioners on issues and importance of sustainable construction. A shift from conventional construction practices to a more sustainable integrated practices is also very desirable. It further recommended for further study that will examine the client's opinion on the factors responsible for clients' resistive behaviour towards the implementation of sustainable construction in Nigeria.
Author contributions: All co-authors have involved in all stages of this study while preparing the final version. They all agree with the results and conclusions.

Funding: No external funding is received for this article.

Declaration of interest: The authors declare that there is no conflict of interest regarding to this study.

Ethics approval and consent to participate: Not applicable. Availability of data and materials: All data generated or analyzed during this study are available for sharing when appropriate request is directed to corresponding author.

\section{REFERENCES}

Adros, N. A. and Abidin, D. N. Z. (2019). An investigation of the diversification roles of contractor. SEISENSE Journal of Management, 2(2), 1-12. https://doi.org/10.33215/ sjom.v2i2.93

Aghimien, D. Aigbavboa, C.C. Ngcobo, C. and Thwala, W. (2019a). Barriers of sustainable construction practices in Nigeria. Proceedings of the 13th Built Environment Conference - Technology, Theory, Truth: Constructing a Sustainable Built Environment, Durban, South Africa, 2-3 September, 2019.

Aghimien, D., Aigbavboa, C. and Thwala, W. (2019b). Microscoping the challenges of sustainable construction in developing countries. Journal of Engineering, Design and Technology, 17(6), 1110-1128. https://doi.org/10.1108/ JEDT-01-2019-0002

Al Amri, T. and Marey-Pérez, M. (2020). Key quality issues affecting the sustainability of construction projects in Oman. International Journal of Advanced Science and Technology, 29(3), 4330-4338.

Alzahrani, J. I. and Emsley, M. W. (2012). The impact of contractors' attributes on construction project success: A post construction evaluation. International Journal of Project Management, 31(2), 313-322. https://doi.org/ 10.1016/j.ijproman.2012.06.006

Amarantou, V., Kazakopoulou, S., Chatzoglou, P. and Chatzoudes, D. (2016). Factors affecting "resistance to change": An explanatory study conducted in the healthcare sector. International Journal of Strategic Innovative Marketing. https://doi.org/10.15556/IJSIM.03.03.003

Amarantou, V., Kazakopoulou, S., Chatzoudes, D. and Chatzoglou, P. (2018). Resistance to change: An empirical investigation of its antecedents. Journal of Organisational Change Management, 31(2), 426-450. https://doi.org/ 10.1108/JOCM-05-2017-0196

Ametepey, O., Aigbavboa, C. and Ansah, K. (2015). Barriers to successful implementation of sustainable construction in the Ghanaian construction industry. Procedia Manufacturing, 3, 1682-1689. https://doi.org/10.1016/ j.promfg.2015.07.988

Angonese, R. and Lavarda, C. E. F. (2014). Analysis of the factors affecting resistance to change in management accounting systems. Revista Contabilidade \& Finanças, 25(66), 214-227. https://doi.org/10.1590/1808-057x 201410810 
Armenakis, A. A. and Harris, S. G. (2009). Reflections: Our journey in organisational change research and practice. Journal of Change Management, 9(2), 127-142. https://doi.org/1080/14697010902879079

Bartlett, J. E., Kotrlick, J. W. and Higgins, C. C. (2001). Organizational research: Determining appropriate sample size in survey research. Information Technology, Learning, and Performance Journal, 19(1), 43-50.

Bonanomi, M., Paganin, G. and Talamo, T. (2016). BIM implementation in design firms. Risk-response strategies to support change management. $41^{\text {st }}$ IAHS World Congress on Sustainability and Innovation for the Future, 13-16 September 2016, Albufeira, Algarve, Portugal.

Bouckenooghe, D. (2010). Positioning change recipients' attitudes toward change in the organisational change literature. Journal of Applied Behavioural Science, 46(4), 500-531. https://doi.org/10.1177/0021886310367944

Bovey, W. H. and Hede, A. (2001). Resistance to organisational change: The role of defence mechanisms. Journal of Managerial Psychology, 16(7), 534-548. https://doi.org/ 10.1108/EUM0000000006166

Brennan, M. and Cotgrave, A. (2013). Development of a measure to assess attitudes towards sustainable development in the built environment: a pilot. In S. D. Smith and D. D. Ahiaga-Dagbui (Eds.), Proceedings of the $29^{\text {th }}$ Annual ARCOM Conference, 2-4 September 2013, Reading, UK, Association of Researchers in Construction Management, pp. 1265-1273.

Chung, S. H., Su, Y. F. and Su, S. W. (2012). The impact of cognitive flexibility on resistance to organisational change. Social Behaviour and Personality: An International Journal, 40(5), 735-745. https://doi.org/10.2224/sbp.2012.40.5.735

Cochran, W. G. (1977). Sampling techniques (3rd Ed.). New York: John Wiley \& Sons Inc.

Courpasson, D. and Valles, S. (2016). Resistance studies: A critical introduction. In D. Courpasson and S. Valles (Eds.), The Sage Handbook of Resistance, London, England: Sage Publications, pp. 1-28. https://doi.org/10.4135/ 9781473957947.n1

Damawan, A. H. and Azizah, S. (2020). Resistance to change: Causes and strategies as an organizational challenge. Advances in Social Science, Education and Humanities Research, 395, 49-53. https://doi.org/10.2991/assehr.k. 200120.010

Daniel, E.I., Oshineye, O. and Oshodi, O. (2018). Barriers to sustainable construction practice in Nigeria. In: C. Gorse and C.J. Neilson (Eds) Proceeding of the $34^{\text {th }}$ Annual ARCOM Conference, 3-5 September 2018, Belfast, UK, Association of Researchers in Construction Management, pp. 149-158.

Davies, O. O. A. and Davies, I. O. E. (2017). Barriers to implementation of sustainable construction techniques. MAYFEB Journal of Environmental Science, 2, 1-9.

Djokoto, S. D., Dadzie, J. and Ohemeng-Ababio, E. (2014). Barriers to sustainable construction in the Ghanaian construction industry: Consultants' perspectives. Journal of Sustainable Development, 7(1), 134-143. https://doi.org/ 10.5539/jsdv7n1p134
Ekolu, S. O. and Quainoo, H. (2019). Reliability of assessment in engineering education using Cronchba's alpha, KR and split-half methods. Global Journal of Engineering Education, 21(1), 24-29.

Erdogan, B., Anumba, C., Bouchlaghem, D. and Nielsen, Y. (2005). Change management in construction: the current context. In F. Khosrowshahi (Ed.), 21st Annual ARCOM Conference, 7-9 September 2005, SOAS, University of London. Association of Researchers in Construction Management, $p p$. 1085-1095.

Esezobor, E. L. (2016). Sustainability and construction: A study of the transition to sustainable construction practices in Nigeria (Doctoral dissertation), Birmingham City University, UK.

Fauzi, S. N. F. M., Yusof, N. A., Awang, H. and Nah, M. N. N. (2018). Factors influencing engineers' attitude towards environmental sustainability. E3S Web of Conferences (ICCEE 2018), 65, 04003. https://doi.org/10.1051/ e3sconf/20186504003

Fiedler, S. (2010). Managing resistance in an organisational transformation: A case study from a mobile operator company. International Journal of Project Management, 28(4), 379-383. https://doi.org/10.1016/j.ijproman.2010. 02.004

Forsell, L. M. and Åström, J. A. (2012). An Analysis of resistance to change exposed in individuals' thought and behaviours. Comprehensive Psychology, 1, 17. https://doi.org/10.2466/09.02.10.CP.1.17

Gilliland, D. and Melfi, V. (2010). A note on confidence interval estimation and margin of error. Journal of Statistics Education, 18(1), 1-8. https://doi.org/10.1080/10691898. 2010.11889474

Gunduz, M. and Almuajebh, M. (2020). Critical success factors for sustainable construction project management. Sustainability, 12, $1990 . \quad$ https://doi.org/10.3390/ su12051990

Hadavinejad, M., Khaef Elahi, A. and Alizadeh Sani, M. (2010). Managers, policy adoption, employees' political perception and resistance to change. Iranian Journal of Management Sciences, 4(16), 119-137.

Hammond, S. F., Savage, D. A., Gajendran, T. and Maund, K. (2019). Stakeholders embrace green construction as the right direction: But as individuals they make selfinterested decisions. CIB World Building Congress, Hong Kong SAR, China, 17-21 June 2019.

Harich, J. (2010). Change resistance as the crux of the environmental sustainability problem. System Dynamic Review, 26(1), 35-72. https://doi.org/10.1002/sdr.431

Harich, J., Bangerter, P. and Durlacher, S. (2012). Solving the sustainability problem with root cause analysis. Proceedings of the Ecosystem Services Partnership Conference, 31 July-4 August 2012, Portland, Oregon, USA.

Hoxha, V. and Shala, F. (2019). The benefits and challenges of sustainable buildings in Prishtina, Kosovo. Facilities, 37(13/14), 1118-1152. https://doi.org/10.1108/F-08-20180097 
Hussin, A. A. and Omran, A. (2009). Roles of professionals in construction industry. The International Conference on Economics and Administration, Faculty of Administration and Business (ICEA - FAA), University of Bucharest, 14-15 November, Romania.

Karaxha, H. (2019). Methods for dealing with resistance to change. Baltic Journal of Real Estate Economics and Construction Management, 7, 290-299. https://doi.org/ 10.2478,bjreecm-2019-0018

Khan, K. and ur Rehman, M. (2008). Employees resistance towards organizational change (MSc. Thesis in Business Administration), Blekinge Institute of Technology School of Management Ronneby, Sweden.

Khan, M. M., Raza, M. A. and Mujtaba, B. G. (2016). Determinants of resistance to organisational change: A qualitative study of a non-governmental organisation in Pakistan. Journal of Educational Leadership and Policy, 1(3), 43-50.

Khourshed, N. F. (2011). The relation between resistance to change and theory of constraints. The Eight International Conference of Global Academy of Business \& Economic Research (GABER), Dubai, U.A.E.

Langstrand, J. and Elg, M. (2012). Non-human resistance in changes towards lean. Journal of Organisational Change Management, 25(6), 853-866. https://doi.org/10.1108/ 09534811211280609

Lee, K. H., Ahn, Y. H., Jeon, M. and Suh, M. J. (2014). Organisational strategies to support sustainability in the construction company. In the World SB14, Barcelona, Spain, 28-30 October 2014.

Lewin, K. (1947). Frontiers in group dynamics: concept, method and reality in social science, social equilibra and social change. Human Relations, 1, 5-41. https://doi.org/10.1177/001872674700100103

Lines, B. C., Sullivan, K., Smithwick, J. B. and Mischung, J. (2015). Overcoming resistance to change in engineering and construction: Change management factors for owner organisations. International Journal of Project Management, 33(5), 1170-1179. https://doi.org/10.1016/j.ijproman.2015. 01.008

Lines, B., Sullivan, K. and Smithwick, J. (2014). An action research approach to implementation of APDMs within AEC owner organisations: Overcoming resistance through education. ASCE Construction Research Congress, Atlanta, GA, USA, 19-21 May 2014, pp. 2084-2085. https://doi.org/10.1061/9780784413517.212

Macrì, D. M., Tagliaventi, M. R. and Bertolotti, F. (2002). A grounded theory for resistance to change in a small organisation. Journal of Organisational Change Management, 15(3), 292-310. https://doi.org/10.1108/ 09534810210429327

Olowosile, S., Oke, A. and Aigbavboa, C. (2019). Barriers to the achievement of sustainable construction projects in Nigeria. Proceedings of the International Conference on Industrial Engineering and Operation Management, Toronto, Canada, 23-25 October 2019, pp. 1002-1010.
Onubi, H. O., Yusof, N. and Hassan, A. S. (2019). Adopting green construction practices: Health and safety implications. Journal of Engineering, Design and Technology, 18(3), 635-652. https://doi.org/10.1108/JEDT-08-20190203

Pakdel, A. (2016). An investigation of the difference in the impact of demographic variables on employees' resistance to organisational change in government organisations of Khorasan Razavi. Procedia - Social and Behavioural Sciences, 230, 439-446. https://doi.org/10.1016/j.sbspro.2016.09.055

Pham, H., Kim, S. and Luu, T. (2020). Managerial perception on barriers to sustainable construction in developing countries: Vietnam case. Environment, Development and Sustainability, 22, 2979-3003. https://doi.org/10.1007/ s10668-019-00331-6

Pham, H., Kim, S. Y. and Luu, T.V. (2019). Managerial perceptions on barriers to sustainable construction in developing countries: Vietnam case. Environment, Development and Sustainability, 2, 1-25. https://doi.org/10.1007/s10668-019-00331-6

Pieterse, J. H., Caneëls, M. C. J. and Homan, T. (2012). Professional discourses and resistance to change. Journal of Organisational Change Management, 25(6), 798-818. https://doi.org/10.1108/09534811211280573

Powmya, A. and Abidin, N. Z. (2014). The challenges of green construction in Oman. International Journal of Sustainable Construction Engineering and Technology, 5(1), 33-41.

Powmya, A., Abidin, N. Z. and Azizi, N. S. M. (2019). Strategizing contractor firms to deliver green construction projects: Conceptual framework. IOP Conference Series: Materials, Science and Engineering, 601, 012027. https://doi.org/10.1088/1757-899X/601/1/012027

Sarhan, J., Xia, B., Fawzia, S., Karim, A. and Olanipekun, A. (2018). Barriers to implementing lean construction practices in the Kingdom of Saudi Arabia (KSA) construction industry. Construction Innovation, 18(2), 246272. https://doi.org/10.1108/CI-04-2017-0033

Schweiger, S., Stouten, H. and Bleijenbergh, I. L. (2018). A system dynamics model of resistance to organisational change: The role of participatory strategies. System Research and Behavioural Science, 35, 658-674. https://doi.org/10.1002/sres.2509

Singh, K. (2015). The study of key factors resistance to change when adoption of new technologies in the companies (Master of Business Administration Thesis), The Graduate School of Bangkok University, Thailand.

Smollan, R. K. (2011). The multi-dimensional nature of resistance to change. Journal of Management and Organisation, 17(6), 828-849. https://doi.org/10.1017/ S1833367200001206

Susanti, B. Filestre, S. F. H. Juliantina, I. (2019). The analysis of barriers for implementation of sustainable construction in Indonesia. The 2nd International Conference on Smart City Innovation, IOP Conference Series: Earth and Environmental Science, 396, 012033. https://doi.org/10.1088/17551315/396/1/012033 
Taherdoost, H. (2017). Determining sample size; How to calculate survey sample size. International Journal of Economics and Management Systems, 2, 237-239.

Tavakol, M. and Dennick, R. (2011). Making sense of Cronbach's Alpha. International Journal of Medical Education, Editorial, 2, 53-55. https://doi.org/10.5116/ ijme.4dfb.8dfd

Thakur, R. R. and Srivastava, S. (2018). From resistance to readiness: The role of mediating variables. Journal of Organisational Change Management, 31(1), 230-247. https://doi.org/10.1108/JOCM-06-2017-0237

Tsoy, D. and Yongqiang, G. (2016). A cross-national study of the relationships between cultural determinants, sustainable governance and sustainable development. International Journal of Management Science and Business Administration, 2(4), 28-43. https://doi.org/10.18775/ ijmsba.1849-5664-5419.2014.24.1003

van Marrewijk, A. (2018). Digging for change: Change and resistance in interorganisational projects in the utilities sector. Project Management Journal, 49(3), 34-45. https://doi.org/10.1177/8756972818770590
Wong, P. S. P. Whelan, B. and Holdsworth, S. (2018). Are contractors ready for greater use of prefabrication in projects? An empirical analysis on the role of unlearning and counter-knowledge. International Journal of Construction Management, 21(4), 353-368. https://doi.org/10.1080/15623599.2018.1539160

Yang, Y. (2014). Understanding resistance to change in different national context - A comparative study between China and Norway (Master of Science in Change Management), University of Stavanger, Norway.

Ybema, S., Thomas, R. and Hardy, C. (2016). Organisational change and resistance: An identity perspective. In: D. Courpasson and S. Valles (Eds), The Sage Handbook of Resistance, Sage Publications: London, England, pp. 386404. https://doi.org/10.4135/9781473957947.n21

Zhang, Y., Luo, Y., Zhang, X. and Zhao, J. (2019). How green human resource management can promote green employee behaviour in China: A technology acceptance model perspective. Sustainability, 11(19), 5408. https://doi.org/10.3390/su11195408 